\title{
Primjena učenja temeljenog na projektima u nastavi tehničke kulture
}

\author{
Mislav Briševac \\ Sveučilište u Rijeci \\ Sveučilišna avenija 4 \\ mislav.brisevac@student.uniri.hr
}

\author{
Damir Purković \\ Sveučilište u Rijeci \\ Sveučilišna avenija 4 \\ damir@uniri.hr
}

\begin{abstract}
Sažetak
Razvoj gospodarstva neke zemlje čvrsto je povezan s razvojem tehnologije i tehničkog odgojno-obrazovnog područja. Tehničko i inženjersko znanje karakterizira raznovrsnost i visoko nepredvidiva dinamika razvoja. Stoga je ovo područje učenja i poučavanja podložno promjenama i usklađivanju s dinamikom razvoja tehnologije te problemima uspješnog ostvarivanja ciljeva nastave. Kako bi se ti problemi neutralizirali, u suvremenu nastavu je potrebno implementirati i kontekstualne pristupe učenju i poučavanju, poput učenja temeljenog na projektima. U ovom radu se elaborira takva implementacija u okviru kurikuluma nastavnog predmeta Tehnička kultura. Kao predložak za implementaciju korišten je model kontekstualnog učenja i razvoja učenika. U tom smislu projektna nastava i učenje zauzimaju središnje mjesto u kurikulumu, tijekom čega se ostvaruje većina ishoda učenja. U radu se ujedno donosi primjer implementacije za 8. razred, što učiteljima i praktičarima može olakšati vlastitu operacionalizaciju kurikuluma. Pri tom učitelj i nadalje ostaje glavni kreator i moderator nastave, pri čemu je važno postaviti određena ograničenja učenicima, predvidjeti prijedloge za rješavanje problema te voditi učenike $k a$ uspješnom dovršetku aktivnosti. Unatoč tome, stvarni učinak primjene ovakvog pristupa na postignuća učenika bit će moguće evaluirati tek ako zaživi u stvarnoj nastavnoj praksi, što se očekuje u skoroj budućnosti.
\end{abstract}

Ključne riječi: kontekstualni pristup, kurikulum, projektna nastava, tehnička kultura, učenje temeljeno na projektima.

\section{Uvod}

U današnje vrijeme svjedoci smo sve bržih i većih promjena u svijetu. Tehnološki razvoj, informacijska revolucija, društvena tranzicija i globalizacijski procesi uvelike mijenjaju paradigmu poučavanja i učenja suvremene nastave. Zbog toga su potrebe za promjenama tradicionalne škole neizbježne. Promjene su usmjerene transformaciji škole od izraženog spoznajnog ustroja ka naglašavanju važnosti socijalnih odnosa i suradničkog učenja. U tom smislu $i$ uloga učenika nije više zasnovana na kvantiteti spoznaje, već na aktivnom stjecanju znanja.
Pri tom se mijenja i uloga učitelja koji organizira, usmjerava, potiče, prati i vrednuje učenički rad, odnosno, voditi učenike kroz svijest povezanu s vlastitim iskustvom i društveno prihvatljivom razumijevanju (Purković, 2013). U tom smislu se postavlja i pitanje primjerenosti metoda, strategija i pristupa učenju i poučavanju. $U$ tom smislu se učenje temeljeno na projektima nameće se kao popularna strategija za maksimiziranje vještina samoučenja $i$ promicanje intelektualnog razvoja učenika uz istovremeno učenje osnova predmeta (Lipika i sur., 2014). Projektno učenje temelji se na konstruktivističkim načelima koja naglašavaju važnost specifičnog nastavnog konteksta (Purković i Bezjak, 
2015) u kojem su učenici aktivno uključeni u proces učenja, te postižu svoje ciljeve društvenim interakcijama i dijeljenjem znanja i razumijevanja (Kokotsaki i sur., 2016). Ovakvo učenje trebalo bi zauzimati središnje mjesto u kurikulumu nastave, pitanjima ili problemskim zadacima voditi studenta ka glavnim konceptima i načelima područja poučavanja, uključivati studentska istraživanja koja traže izniman mentalni napor, dopuštati visoku razinu autonomije i odgovornosti studenata, te pružiti nužan osjećaj autentičnosti kojom se povezuje školovanje i "stvarni svijet“ (Thomas, 2000). Projektno učenje u pravilu započinje određenim zadatkom koji zahtjeva izvršavanje jednog ili više poslova koji dovode do izrade konačnog proizvoda, dizajna, modela, uređaja ili računalne simulacije te koje završava izvješćem i predstavljanjem učinjenog (Prince i Felder, 2006). Stoga se učenje temeljeno na projektima često smatra ključnom komponentom tehničkih i inženjerskih obrazovnih programa (Frost, 2014).

Iz teorijskih i praktičnih razmatranja uočava se da je učenje temeljeno na projektima ujedno i metoda poticanja misaonih kompetencija i stvaranja fleksibilnog okruženja za učenje. Ovaj proces usmjerava učenike na aktivniju ulogu u učenju i nastavi, a heterogene aktivnosti učenja, koje su neizostavne u ovakvoj nastavi, prilagođene su i različitim stilovima učenja i karakteristikama učenika. Drugim riječima, zbog toga što širu populaciju čine učenici čije su osobine, dispozicije, sposobnosti i sklonosti različite, važno je osigurati mogućnost učenja na različite načine: pojedinačno, kolektivno, uz usmjeravanje nastavnika, izravnim iskustvom ili kroz primjere i praktični rad. Projektno učenje pruža učenicima mogućnost da uče prema individualnim stilovima učenja, a omogućuje im da istražuju svoje vještine i sposobnosti u skladu sa svojim planovima.

Implementacija projektne nastave u suvremenu nastavu pruža mnoge i evidentne prednosti učenicima, no pri implementaciji u kurikulum nailazimo i na brojne prepreke. Važnu prepreku čini vrijeme (satnica) koja je često nedovoljna za realizaciju svih planiranih aktivnosti, ali i razrednopredmetno-satni sustav organizacije nastave. Stoga je i cilj ovog rada teorijski potkrijepiti, ali i razraditi mogućnosti implementacije učenja temeljenog na projektima u kurikulum nastave tehničke kulture. Pri tom se $u$ radu elaborira značenje tehničke kulture $u$ sustavu općeg odgoja i obrazovanja, važnost i model kontekstualnog učenja i razvoja učenika, koji se ujedno koristi za implementaciju projektnog učenja u nastavi tehničke kulture. Kao pomoć učiteljimapraktičarima, naposljetku se razrađuje primjer implementacije učenja temeljenog na projektima $u$ kurikulumu tehničke kulture.

\section{Kurikulum i kurikulumski pristup nastavi}

Riječ kurikulum usvojena je iz engleskog jezika (eng. curriculum), a potječe iz latinskog jezika gdje označava hod (tok) kroz pouku (obuku). Ovaj pojam ujedno obuhvaća i učenje i studiranje, odnosno plan i program učenja te sve što je povezano $s$ obrazovanjem. Može se zaključiti kako sama riječ ima složeno značenje te ju je teško prevesti jednom riječju. lako je u hrvatskom jeziku prihvaćen anglizam, neki autori se zalažu za preimenovanje riječi kurikulum u „uputnik“. Zbog složenog značenja, često nailazimo i na različite definicije kurikuluma. Prema Milatu (2005), kurikulum je sustav metodološki precizno odabranih, strukturiranih i metodički oblikovanih sadržaja i pedagoških aktivnosti školovanja određen svrhom, vrstom, oblikom i razinom škole za koju je izrađen. Kurikulumom su određeni svrha i ciljevi učenja i poučavanja nastavnog predmeta, struktura određenog predmeta u odgojno-obrazovnom procesu te odgojno-obrazovni ishodi ili sadržaji. Također su navedeni i pripadajuća razrada i opisi razina usvojenosti ishoda, načini učenja i poučavanja te vrednovanje $u$ pojedinom nastavnom predmetu. Obrazovanje se u Hrvatskoj trenutno ostvaruje na temelju nacionalnog kurikuluma, nastavnih planova $\mathrm{i}$ programa te školskog kurikuluma, a tek od kurikularne reforme i na temelju predmetnih kurikuluma.

Pedagoška teorija i praksa na različite načine pristupa kategorizaciji i klasifikaciji kurikuluma. Sa stajališta primjene suvremenih pristupa i strategija učenja, kao što je učenje temeljeno na projektima, važno je kurikulum razmatrati s obzirom to koliku autonomiju ima nastavnik pri njegovoj operacionalizaciji. Riječ je o otvorenosti kurikuluma, pri čemu se razlikuju tri vrste kurikuluma (Jukić, 2010):

a) zatvoreni - često se izjednačava s tradicijskim shvaćanjem nastave. Nastavni sadržaj je raspodijeljen na teme i sadržaje (kronološki slijed događaja) i implementiran u nastavu kroz godine učenja i broj sati. S obzirom da je su sadržaji kruto propisani, ovakav kurikulum limitira učenike, a i učitelje u kreativnosti i slobodi pri realizaciji nastave te pri ostvarivanju ciljeva nastave i ishoda učenja.

b) otvoreni - omogućuje stvaralački pristup učenika tako što umjesto strogo definiranih uputa nudi smjernice i okvirne upute za izvedbu nastave. Karakterizira ga fleksibilnost u odabiru sadržaja i načina rada. Za razliku od zatvorenog kurikuluma, naglasak je na socijalnokomunikacijskom odnosu između nastavnika, 
učenika i roditelja. Drugim riječima, propisani su samo vrlo okvirni sadržaji i ciljevi (ishodi) učenja, dok se razrada sadržaja, izbor metoda, strategija i pristupa nastavi prepušta nastavniku.

c) mješoviti - smatra se suvremenim oblikom kurikuluma. Temelj ovakvog kurikuluma čini jezgra, kao radna cjelina koju nastavnik zajedno s učenicima pretvara u kreativni projekt ili istraživački i radni zadatak. Takav rad aktivira učenika pri stjecanju znanja, vještina i razvoju sposobnosti. U ovakvom kurikulumu propisana je struktura sadržaja, ciljevi i ishodi učenja, ali i načini realizacije $i$ evaluacije učenika dok je nastavnik odgovoran za razradu sadržaja i vrsta aktivnosti u nastavi.

Danas se u mnogim područjima nastave pokušava promicati otvoreni kurikulum, iako to često ne nailazi na odobravanje tradicionalno orijentiranim obrazovnim sustavima kakav je hrvatski. Naravno da je za pojedine predmete i područja ponekad neophodno slijediti načine i rad zatvorenog kurikuluma, no i za njih se mogu osmisliti aktivnosti koje bi osiguravale fleksibilnost nastavnog rada $\mathrm{i}$ aktivnije stjecanje znanja od strane učenika.

\section{Izazovi implementacije suvremenih nastavnih strategija $u$ kurikulum}

Implementacija suvremenih nastavnih strategija i pristupa u kurikulum, poput učenja temeljenog na projektu, nailazi i na mnoge poteškoće i izazove. One se dijele $u$ dvije kategorije, a to su one koje predstavljaju izazov učiteljima te one koje predstavljaju izazov školama. Prvu prepreku pri implementaciji učenja temeljenog na projektima često čini i samo nerazumijevanje ovog pojma, pri čemu se svaka složenija praktična aktivnost često smatra takvom strategijom. Ovo je velika zabluda, zbog čega je i ovaj pojam potrebno pojasniti. U tom smislu je potrebno naglasiti kako se projektno učenje temelji se na konstruktivističkim načelima koja naglašavaju važnost specifičnog nastavnog konteksta (Purković i Bezjak, 2015) u kojem su učenici aktivno uključeni u proces učenja, te postižu ciljeve nastave društvenim interakcijama te dijeljenjem znanja i razumijevanja (Kokotsaki i sur., 2016). Da bi se neka nastava mogla nazvati projektnom mora udovoljavati važnim kriterijima: a) treba zauzimati središnje mjesto u kurikulumu nastave, b) pitanjima ili problemskim zadacima voditi učenika ka glavnim konceptima i načelima područja poučavanja, c) uključivati učenička istraživanja koja traže izniman mentalni napor, d) dopuštati visoku razinu autonomije i odgovornosti učenika, te e) pružiti nužan osjećaj autentičnosti kojom se povezuje školovanje i "stvarni svijet" (Thomas, 2000). U pravilu, učenje temeljeno na projektima započinje određenim zadatkom koji zahtjeva izvršavanje jednog ili više poslova koji dovode do izrade konačnog proizvoda, dizajna, modela, uređaja ili računalne simulacije te koje završava izvješćem i predstavljanjem učinjenog (Prince i Felder, 2006). Iz ovakvih određenja i kriterija je jasno da svaki projekt nije istovremeno i nastava temeljena na projektima.

Problemi pri implementaciji nastave i učenja temeljenog na projektima su često povezani i s kompetencijama nastavnika. Tako je nekim nastavnicima teško pokrenuti projekt, pogotovo ako ga nisu samostalno osmislili. To potvrđuje tezu kako nastavnik treba biti kreator vlastite nastave. Naime, iako su danas mnogi primjeri projekata i dobre prakse široko dostupni, takvi materijali nisu dostatni za uspješnu realizaciju projektne nastave, već samo mogu doprinijeti da učenici lakše razrade neku ideju, pod pretpostavkom da je ideja učenička. Druga poteškoća se očituje u vidu upravljanja vremenom. Učitelji za provođenje učenja temeljenog na projektima moraju imati sposobnosti savršenog upravljanja vremenom kako bi se sve planirane etape projekta mogle provesti. Zbog toga su izbor određenog modela projektne nastave, detaljna priprema projekta, predviđanje vremena i ključnih točaka (zastoja i načina vođenja) te sadržajna i komunikacijska priprema iznimno važan preduvjet uspješne realizacije projekta. Određene „tehničke“ poteškoće su također važan čimbenik pri provedbi projekta. Osim što prolaze kroz vremenska ograničenja, učitelji nailaze i na prepreke poput demotiviranosti i nediscipline učenika pri praćenju i provedbi aktivnosti te utvrđenih procedura. Učenička disciplina u dovršavanju projekata stoga postaje „tehnička“ prepreka pa je i time otežana implementacija projektne nastave. Pri takvim problemima rezultat projekta nije maksimalan, posebno na vrsti projekta čiji rezultati su stvarni i funkcionalni proizvodi. Ograničeno vrijeme i nedostatak vještina prisiljavaju učenike da brzo završe projekt zbog čega izostaje očekivani rezultat. U takvim slučajevima se učitelji više brinu o procesu nego o rezultatima, što i nije tako pogubno. Naime, proces kojim se modelira ponašanje i svijest učenika predstavlja najvrjedniji produkt učenja temeljenog na projektima, osobito ako učenici pri tom postanu homogena i angažirana skupina. Stoga nastavnik treba posvetiti učenicima dovoljno vremena prilikom pripremanja projekta, razrade ideje i dogovaranja pravila rada i ponašanja.

Teškoće koje predstavljaju izazov školama očituju se u organizaciji rada škole gdje se učitelji susreću s fiksiranim i neadekvatnim resursima, nemogućnosti 
kreiranja fleksibilnog rasporeda nastave kao i s neodgovarajućom nastavnom tehnologijom (Visković, 2016). Škole uglavnom nemaju dovoljno sredstava potrebnih za optimizaciju proces rada. Zbog veličine i brojnosti učenika u razredu dolazi do problema pri implementaciji projektne nastave $s$ obzirom na kurikulum koji je utvrđen na nacionalnoj razini. Prema Thomasu (2000), problemi implementacije nastaju prvenstveno zbog fizičke organizacije škole, vremenskih ograničenja koja proizlaze iz stvarnih potreba učenika za učenjem te potreba učitelja za vremenskim strukturiranjem nastavnog procesa. Kako bi se otklonile ove poteškoće, nužno je preoblikovati strukturu rada u razrednim odjelima te pratiti i vrednovati aktivnosti i rezultate projektne nastave na najbolji mogući način. Učitelji pri tom moraju posjedovati specifična znanja koja stječu u okviru cjeloživotnog usavršavanja, a koje se treba odvijati uz potporu škole i obrazovnog sustava. S obzirom da se svaka nastava odvija prema konceptu kojeg je osmislio učitelj, važno je da učitelj zna što radi i što točno od učenika želi postići. Stoga valja naglasiti kako rezultat projektnog učenja i nastave nije proizvod kojeg učenici izgrade nego njihovo znanje, vještine i usvojene vrijednosti koje steknu tijekom takve nastave. $U$ tom smislu je važan $i$ koncept tehničkog odgoja i obrazovanja, na kojem je zasnovan i novi kurikulum, a koji kreće od postavke kako su objekti tehnike (tvorevine) osnova svake tehničke spoznaje. Pri tom učitelj mora učenicima dati uvid u tvorevine koje je odabrao za vlastitu nastavu, provesti aktivnosti s tvorevinama koje su učenicima svrhovite $i$ smislene te učenicima dati priliku da kritički o tome raspravljaju. Na taj način učenici stječu iskustvo pri razvoju i/ili korištenju proizvoda ili tehnologije, predstavljaju vlastite rezultate, o tome razgovaraju, te tako grade vlastito znanje i shvaćaju važnost tehnike i tehnologije za njih i za društvo (Purković, 2016).

\subsection{Analiza kurikuluma tehničke kulture}

Kako bi se mogla provesti implementacija bilo kakve složene strategije učenja i poučavanja u nastavu nužno je analizirati okvir u kojem se to može izvesti. Za nastavu tehničke kulture to je predmetni kurikulum tehničke kulture za učenike od 5 . do 8. razreda osnovne škole (NN 7/2019). Na početku ovog dokumenta nalazi se opis nastavnog predmeta koji govori o tome kako tehnička kultura uvodi učenike u svijet tehnike i omogućava razumijevanje tehnike $\mathrm{i}$ čovjekovog tehničkog okruženja. Razumijevanje tehnike uključuje različite dobrobiti, no sukladno tome i neke moguće opasnosti.

Prema kurikulumu tehnika se upoznaje na dva načina, kao tvorevina te kao vještina. Naglasak je upravo na upoznavanju tehnike razvijajući vještine učenika samostalnim radom, postupkom primjene znanja i uporabom dokumentacije te izradom i korištenjem tehničkih tvorevina. Zbog lakšeg izvođenja vježbi i samog rada, predviđeno je da se nastava organizira kao blok sat u trajanju od dva školska sata po 45 minuta. Fond sati nastavnog predmeta je 35 sati godišnje uz preporuku za povećanje fonda sati. lako je prvotno zamišljeno da se nastava organizira s pola razrednog odjela, zbog udovoljavanja sigurnosnim i pedagoškim normama, kasnijom izmjenom kurikuluma je to onemogućeno.

Slijede odgojno-obrazovni ciljevi učenja i poučavanja tehničke kulture od kojih se mogu izdvojiti sljedeći:

- povezivati činjenična $i$ teorijska znanja o tehničkim tvorevinama, sustavima i procesima te o prirodoznanstvenim $i$ društvenim osnovama njihova djelovanja;

- primjenjivati vještine uporabe (čitanja) i izrade tehničke dokumentacije, kritički prezentirati svoj rad, razvijati kreativnost u osmišljavanju izgleda i djelovanja tvorevina;

- razvijati znanja, vještine i stavove potrebne za sigurno i svrsishodno korištenje $i$ održavanje tehničkih tvorevina za njihov kritički odabir s obzirom na svojstva $i$ namjenu te $s$ ciljem spoznavanja osobnih mogućnosti, sklonosti $i$ interesa;

- istraživati ulogu i utjecaje tehnike na razvoj društva i kvalitetu života, na prirodni okoliš $i$ na održivost materijalnih i energetskih resursa, usvojiti znanja za kritički pristup pri procjeni dobrobiti tehnike u radu i svakodnevnome životu.

- analizirati i razmatrati stavove $i$ vrijednosti prema osobnome i suradničkome radu, kritički vrednovati svoj i tuđi rad, prepoznati interese $i$ sklonosti u vezi s nastavkom obrazovanja te postaviti osnove za izbor budućega zanimanja $i$ usvojiti potrebu stalnoga usavršavanja $i$ cjeloživotnoga učenja, razvijati poduzetnost $u$ stvarnome životu i tehničkome okružju.

Ciljevi nastave tehničke kulture su navedeni tako da vode ka razvoju generičkih kompetencija koje su predviđene Okvirom nacionalnoga kurikuluma. lako bi okvir nacionalnog kurikuluma trebao biti krovni okvir obrazovanja, ovaj dokument je još uvijek je u fazi prijedloga. lako bi se iz ciljeva jasnije trebalo moći razlučiti koja znanja i na kojoj razini se od učenika očekuju te koje vještine i odgojne vrijednosti učenik treba usvojiti, analizom se može uočiti da je naglasak stavljen na grafičko komuniciranje, samospoznaju, ekologiju i suradničke kompetencije. Uzimajući u obzir stvarnu nastavnu praksu, u kojoj se forsiraju i nameću individualne aktivnosti učenika, već na prvi pogled je jasno da su ciljevi neostvarivi. Stoga se jedino primjenom suvremenih nastavnih 
strategija, poput projektnog učenja i nastave, mogu ostvariti takvi ciljevi.

Nadalje, kurikulum je strukturiran prema domenama i odgojno-obrazovnim ishodima koji su razrađeni za svaki razred i svaku domenu učenja $i$ poučavanja. Pri tom se ističe kako se usvajanjem znanja o tehničkim tvorevinama, razvijanjem vještina koje omogućuju kreativnost i inovativnost pri dizajniranju i izradi tehničkih tvorevina te kritičkim razmišljanjem o tehnici s ekološkog, ekonomskog i društvenog aspekta stječe opća tehnička kultura.

Domene u kurikulumu su: A: Dizajniranje i dokumentiranje, B: Tvorevine tehnike i tehnologije i C: Tehnika i kvaliteta života. Važno je naglasiti kako te domene nije moguće izjednačiti $s$ nastavnim cjelinama, već su to određeni spoznajni konstrukti koji se međusobno prožimaju $\mathrm{i}$ čine jedinstvenu tehničku spoznaju. Pri tom su u kurikulumu istaknuta preklapanja domena, kao i domena s cjelinama generičkih kompetencija, što se jasno vidi iz grafičkog prikaza u kurikulumu. lako su domene u načelu dobro zamišljene iz njihova pojašnjenja se može uočiti da ne slijede teorijski okvir konceptualizacije tehničkih znanja (Purković, 2018), već su više usklađene s nepostojećim okvirom nacionalnog kurikuluma.

U kurikulumu je istaknuta i povezanost tehničke kulture s ostalim predmetima zbog čega sadržaji često interferiraju sa sadržajima matematike, likovne kulture, informatike, pa i povijesti i ostalih predmeta. Navedeni su još i načini poučavanja, uloga učitelja te materijali i izvori koji se koriste na predmetu.

Posljednji dio kurikuluma zaključuje se vrednovanjem učenika, a tu su naglašena tri standardna pristupa: vrednovanje za učenje (formativno vrednovanje), vrednovanje kao učenje (samovrednovanje) i vrednovanje naučenog (sumativno vrednovanje). Vrednovanje se ostvaruje primjenom različitih metoda koje uključuju usmeno provjeravanje, vrednovanje grafičkih radova, laboratorijskih vježbi, izrađenih tehničkih tvorevina i prezentacija. lako se to izrijekom ne navodi, ali sustav tehničkih znanja je nužno vrednovati i pismenim provjerama, jer se na taj način omogućuje vrednovanje tehničko-tehnoloških znanja, ali i složenih grafičko-motoričkih i spoznajnih vještina učenika. Posebnost predmeta je mogućnost vrednovanja odgojno-obrazovnih ishoda u svim komponentama putem praktičnih radova, pri čemu učitelj osmišljava elemente vrednovanja.

$\mathrm{Na}$ kraju dokumenta priložena je Matrica odgojno-obrazovnih ishoda. Za svaki razred navedeni su uopćeni odgojno-obrazovni ishodi koji bi trebali proizaći iz učenikova učenja predmeta. Navedena je i razrada tih ishoda, odnosno detaljniji opis aktivnosti. Pored svega, nalazi se razina usvojenosti u kojima su opisani kriteriji prema kojima se procjenjuje učenikovo znanje. lako su ishodi dobro osmišljeni i odgovaraju razini znanja i učenikovoj dobi za svaki razred osnovne škole, njihova konkretizacija je prepuštena učitelju. Naime, obveza svakog učitelja je osmisliti vlastiti godišnji izvedbeni (operativni) kurikulum, pri čemu mu ovaj kurikulum treba biti vodič. Drugim riječima, učitelj treba ostvariti ishode koje je sam definirao, a koji trebaju činiti konkretizaciju ishoda učenja iz ovog kurikuluma.

Potrebno je istaknuti kako se u suvremenim pristupima učenju poučavanju tehnike misaoni i praktičan rad učenika integriraju $u$ jedinstvenu cjelinu, što se i u ovom kurikulumu ističe. Stoga nastava tehničke kulture treba svakom učeniku omogućiti doživljaj užitka stvaranja i zadovoljstva vlastitim radom, čime se ujedno razvija samostalnost i odgovornost učenika, svijest o vlastitim interesima i mogućnostima, samopoštovanje kao i socijalne vještine koje uključuju i uvažavanje drugih. Pri tom kontekst u kojem će se odvijati učenje i poučavanje ima presudnu ulogu, zbog čega se često mnogi suvremeni pristupi nazivaju i kontekstualni pristupi nastavi.

\section{Kontekstualni pristup nastavi kao okosnica implementacije projektnog učenja}

Kontekst je pojam koji se najprije koristio u lingvistici, a potom je ušao u područje psihologije kao pojam koji često označava temelj ljudskog spoznavanja. Određen je kognitivnim procesom iz kojeg proizlazi smisao i značenje kroz korelaciju $s$ različitim sadržajima poput pojmova, slika, vrijednosti i sličnih sadržaja. lako mnogi smatraju Johna Deweya, američkog obrazovnog reformatora, začetnikom ideje kontekstualnog pristupa učenju i poučavanju, ruski obrazovni psiholog Verbitsky razvio je kontekstualno učenje i poučavanje kao teoriju poučavanja ili profesionalnog osposobljavanja (Purković i Bezjak, 2015). Verbitsky je 1981. godine predstavio i opisao svoju teoriju te njezin značajan potencijal za teoriju i praksu obrazovanja. Pri tom je formulirao i definiciju psihološkog konteksta kao sustava unutarnjih i vanjskih čimbenika te uvjeta ljudskog ponašanja i djelovanja koji mogu utjecati na percepciju, razumijevanje i transformaciju određene situacije te koji određuju značenje i smisao situacije u cjelini, uključujući i njezine komponente (Verbitsky i Kalashnikov, 2012). Ovaj pojam ubrzo ušao i u učenje i poučavanje jer se shvatilo kako učenik bolje usvaja određene sadržaje i informacije ako su one povezane s kontekstom onoga što on već o tome zna i može učiniti. Stoga se sve one strategije i pristupi učenju i poučavanju pri kojima kontekst učenja, koji daje učeniku smisao i značenje onoga što uči, nazivaju kontekstualni pristupi. Učenje koje se odvija 
primjenom takvih pristupa se još naziva i kontekstualno učenje. Brown (1998) navodi četiri temeljne vrste kontekstualnog učenja:

a) Situacijsko učenje - odnosi se na stjecanje znanja i vještina koje će se koristiti u određenoj situaciji poput posla, zanimanja ili svakodnevne situacije. Situacije učenja odražavaju situacije iz stvarnog svijeta, što daje značaj takvom učenju. Stoga učenje ne treba gledati kao prijenos apstraktnog i kontekstualiziranog znanja između pojedinaca, već kao socijalni proces $s$ određenim uvjetima koji uključuju aktivnost, kontekst i kulturu.

b) Kognitivno naukovanje - je poučavanje autentičnih aktivnosti kroz iskustvo. Učitelj modelira određenu aktivnost te misaono $\mathrm{i}$ iskustveno vodi i usmjerava učenike u procesu stjecanja vještina promatranja, tumačenja $i$ kontekstualizacije sadržaja. Cilj je razviti kognitivne i metakognitivne strategije potrebne za procesuiranje znanja.

c) Učenje usluga - u ovoj vrsti učenja osnovu za učenje predstavljaju problemi stvarnog svijeta koje učenici rješavaju kao tržišnu uslugu tom svijetu. $\mathrm{Na}$ ovaj način učenici u praksi primjenjuju novostečeno znanje ili razvijaju nova znanja i vještine, a sve prema potrebama zajednice kroz projekte i aktivnosti (Berns i Erickson, 2001).

d) Radno zasnovano učenje - uključuje radne aktivnosti i smatra se jednom od najvažnijih vrsta ili praksi kontekstualnog učenja. U ovoj strategiji kontekstualnog učenja dolazi do izražaja učenje kroz akciju, učenje u situaciji te nenamjerno učenje kao spontano djelovanje (Purković i Bezjak, 2015).

\subsection{Strategije i modeli kontekstualnog učenja}

Kurikulum koji se temelji na kontekstualnim pristupima i strategijama učenja treba biti strukturiran tako da potiče pet bitnih aktivnosti. Ove aktivnosti se često nazivaju i ključne strategije učenja i poučavanja tehnike i inženjerstva (CORD, 1999; Crawford, 2001), a uključuju:

1. Povezivanje (Relating),

2. Iskustveno proživljavanje (Experiencing),

3. Primjenu (Applying),

4. Suradnju (Cooperating),

5. Prijenos (Transferring).

Nazvane su REACT strategije prema početnim slovima svake navedene radnje (aktivnosti ili strategije), koje ujedno predstavljaju i prirodni slijed učenja i poučavanja tehnike. U smislu učenja, ove strategije izgledaju "prirodno", ali učitelji ne mogu unaprijed zaključiti jesu li učenici svjesni strategija koje će im pomoći naučiti, zadržati i primijeniti informacije. Stoga bi učenicima trebalo omogućiti iskustva učenja iz REACT strategija te ih informirati o tome zašto su izabrane nastavne metode koje zahtijevaju njihovo aktivno sudjelovanje. Nadalje, učenike treba naučiti kako pažljivo promatrati i bilježiti podatke te kako učinkovito komunicirati kao dio skupine. Strategije REACT osmišljene su kako bi pomogle učenicima $u$ izgradnji novih vještina i znanja, bez obzira na njihovo polazište, odnosno, početnu razinu znanja.

Pri učenju u kontekstu životnog iskustva prakticira se povezivanje pa tako svakodnevni pogledi, događaji i uvjeti omogućavaju učenicima da poznate situacije povežu s novim informacijama koje će se obraditi ili s problemima koje treba riješiti u nastavi. Iskustveno proživljavanje ili učenje u kontekstu istraživanja, otkrića i izuma je bit kontekstualnog učenja. Koliko god bi učenici mogli postati motivirani ili prilagodljivi i primjenom drugih strategija učenja i poučavanja (multimedijalne ili tekstualne aktivnosti), to i dalje ostaju relativno pasivni oblici učenja. Također, učenje je daleko brže kada učenici mogu manipulirati sredstvima i materijalima. Primjena ili učenje korištenjem novih koncepata $i$ informacija $u$ korisnom kontekstu omogućava učenicima doživljaj uspjeha vlastitim angažmanom. Na taj način ujedno mogu zamisliti (predočiti) i budući uspjeh u vlastitom životu ili u karijeri nakon školskog obrazovanja. U kontekstualnom učenju primjena se često temelji na radnim aktivnostima poput autentičnih i stvarnih zadataka ili onih koji odražavaju probleme iz stvarnog svijeta. Ova kontekstualna iskustva učenja mogu se nadopuniti prezentacijama gostujućih sudionika, na način da učenici dožive iskustva iz "prve ruke“ kao što su obilasci postrojenja, mentorski aranžmani i prakse. Suradnja ili učenje u kontekstu dijeljenja i komuniciranja s drugima je primarna strategija poučavanja u kontekstualnoj nastavi. Iskustvo suradnje ne pomaže samo većini učenika da nauče sadržaj, nego je i u skladu s fokusom stvarnog svijeta kontekstualne nastave. Naime, poslodavci neovisno o vrsti posla cijene zaposlenike koji mogu učinkovito komunicirati, koji slobodno dijele informacije i koji mogu raditi kao pripadnici tima. No da bi se takve vještine razvile potrebno ih je prakticirati tijekom procesa školovanja. Stoga postoji dovoljno razloga kojima se potiče učenike da istovremeno razvijaju ove suradničke vještine dok su još uvijek u učionici gdje je taj postupak olakšan. Prijenos ili učenje u kontekstu postojećeg znanja koristi se i nadograđuje na temelju već postojećeg znanja učenika. Prenošenje poznate informacije $u$ novi kontekst pomaže učenicima da pristupe nepoznatoj situaciji ili problemu sa samopouzdanjem. Strategija prijenosa ili transfera stečenog i već primijenjenog znanja u novi kontekst je ključna za ovladavanje vještinama 
rješavanja problema, ali i za razvoj metakognitivnih vještina, poput mogućnosti samovrednovanja ili pronalaženja vlastitih putova učenja.

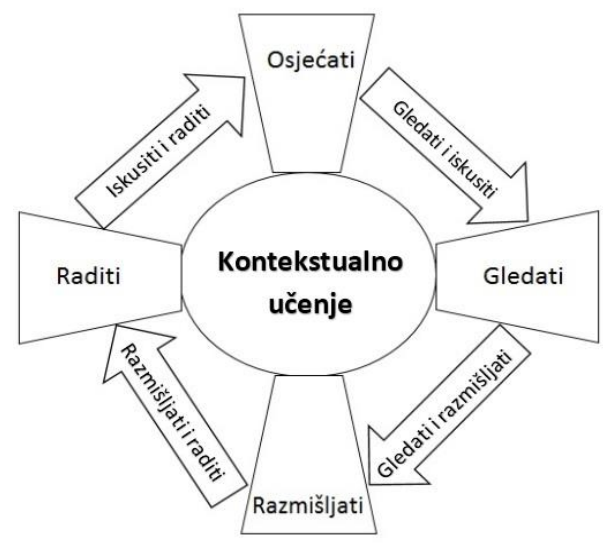

Slika 1. Model kontekstualnog učenja

Proces učenja (slika 1) trebao bi obuhvatiti četiri etape (vrste) učenja: osjećaj, gledanje, razmišljanje i vlastiti rad na konkretnom zadatku (CORD, 1999). Kada se sve četiri vrste ili etape učenja koriste u procesu nastave, učenje se može smatrati optimalnim. Ovaj model se ustvari oslanja na Kolbov model iskustvenog učenja (Kolb, 1984), ali i na slične prethodne modele iskustvenog i eksperimentalnog učenja koje je potaknuo početkom prošlog stoljeća John Dewey. Ovaj model se razlikuje u tome što je u središtu ovakvog učenja kontekst koji učenicima treba biti smislen i dati im značenje onoga što uče i rade u nastavi.

\subsection{Kontekstualni pristupi u nastavi tehničke kulture}

Kada se kontekstualni pristupi prilagode razini obrazovanja i posebnostima nastave tehničke kulture, kao posebnosti obrazovanja u Hrvatskoj, dobivaju se sljedeći konkretni pristupi nastavi (Purković i Bezjak, 2015):

a) Projektna nastava - uključuje izradu konkretnog uratka ili proizvoda. Učenici najprije moraju osmisliti uradak ili proizvod, zatim ga izraditi $i$ prezentirati. Poslije prezentiranja treba provesti diskusiju i naposljetku refleksiju. Tijekom realizacije projekta prisutna je suradnja učenika na koncipiranju, planiranju i afirmiranju tehničke tvorevine. Osim suradničkog rada, izražene su i aktivnosti koje uključuju kritičko i kreativno razmišljanje te povezivanje sadržaja iz različitih područja $s$ aktualnim ciljem. Učenici dolaze do mogućnosti rada $s$ različitim elementima nastavnog konteksta, a to su najčešće tehnički materijali i tehnička sredstva (alati, uređaji, instrumenti) te tehnička dokumentacija, ali i multimedijalni sadržaji (razne računalne aplikacije i simulacije). Purković (2016) ističe kako je projektna nastava najvažnija za razvoj tehničkih kompetencija. Tehničke kompetencije su posebna ponašanja u sklopu tehničkog područja djelovanja, a formiraju se integracijom znanja, sposobnosti i vještina koje su potrebni za uspješno provođenje aktivnosti.

b) Učenički kampovi, vrtovi, radionice - mogu predstavljati radno zasnovano učenje, ali $i$ prilagođeni oblik uslužnog učenja gdje učenici prakticiraju složene poslove. Produkt rada ili moguća usluga donose materijalnu korist školi, a učenicima razvoj i školska postignuća. Sukladno potrebama i problemima škole planiraju se i provode aktivnosti, kritički se analizira rad i iznose se učinci rada. Mogu se provoditi u školskom okružju, ali i terenski u objektima gdje postoji potreba za obavljanjem neke aktivnosti ili pružanja usluge.

c) Stručne ekskurzije - poseban i neizostavan oblik edukacije tehnike. Svrha je upoznati tehniku i tehnologiju u stvarnim okolnostima i uvjetima te upoznati radno-socijalne i proizvodnoekonomske uvjete rada. Ove okolnosti i uvjete nije moguće simulirati niti na neki drugi način upoznati. Stručne ekskurzije se održavaju s ciljem povezivanja teorije s praksom i razvoja tehničkog mišljenja. Prema Bezjak (2009), ekskurzija se u nastavi tehničke kulture može izvoditi po modelu projektne nastave, a može biti i dio problemski zasnovanog učenja. Najvažnije aktivnosti učenika su suradnja pri izradi izvješća i prezentiranju radova te kritičko razmišljanje, diskusija i refleksija o radovima.

d) Problemska nastava - predstavlja rad na kompleksnom tehničkom problemu koji reflektira problem iz stvarnog svijeta. Odvija se u učionici na simuliranim sadržajima kojima autentičnost daju stvarni problemi. Stvarni se problemi koriste kao kontekst, a učenici će rješavajući iste naučiti kritički razmišljati, prikupljati i sređivati podatke te naučiti donositi ispravne odluke. Razvijaju se vještine za samostalno učenje i procjenu postignuća, što iznimno pogoduje tehničkom odgoju i obrazovanju učenika. Tehnički problem je uvijek složen, odnosno misaoni je i praktičan. Pristup rješavanju tehničkog problema je projektni i sveobuhvatan, a rješavanje problema se odvija kroz istraživački rad.

e) Usidrena nastava - učenje na temelju različitih audiovizualnih sadržaja koji prikazuju autentične tehničke, tehničko-tehnološke ili problemske situacije. Ovakva vrsta nastave dio je 
situacijskog učenja, a kod učenika potiče smislenost i svrhovitost učenja i poučavanja. Pritom se učenicima predstavlja tzv. makrokontekst tehničko-tehnološke stvarnosti. Cilj je učenike usmjeriti na promišljanje te im pomoći da postanu neovisni, odnosno da sami uče putem usidrenih materijala. Prema Blacku i McClintocku (1995), učenike treba osposobiti za vlastito i višestruko tumačenje sadržaja te in kognitivnim naukovanjem voditi kroz proces spoznavanja. S obzirom dob učenika i razinu znanja često ih nije moguće upoznati $s$ problemima i situacijama izravno već im je uvit u stvarnost potrebno predočiti putem učinkovitog medija - filmova izvorne stvarnosti.

f) Izolirane praktične aktivnosti - čine važan segment svakog tehničkog odgoja i obrazovanja. lako se često ne smatraju „pravim“ kontekstualnim učenjem učenici tijekom ovih aktivnosti dolaze u doticaj sa stvarnim svijetom. Pritom učenici rade $s$ tehničkim materijalima, tvorevinama i primjenjuju određenu tehnologiju. Time se razvijaju vještine $i$ kompetencije, čime se učenici osposobljavaju za realizaciju složenih kontekstualnih aktivnosti (Purković i Bezjak, 2015).

Može se zaključiti da su suradnički rad te angažiranost učenika u nastavi prisutni u svakom od navedenih pristupa, kao i refleksija te vrednovanje postignuća učenika. Evaluacija postignuća se provodi na osnovu konkretnih rezultata koji proizlaze iz rada učenika. Kako bi se osiguralo da se za ostvarivanje ciljeva nastave i ishoda učenja odabere odgovarajuća aktivnost, potrebno detaljno analizirati ishode učenja iz kurikuluma i utvrditi što bi učenici mogli raditi kako bi ostvarili predviđene ishode. Ujedno je potrebno analizirati elemente nastavnog konteksta koji će imati optimalni utjecaj na kognitivne procese, razvoj vještina i postizanje visokih postignuća učenika. Uzimajući u obzir zahtjeve iz kurikuluma, polazišta i preporučene kontekstualne pristupe nastavi te organizacijska i vremenska ograničenja nastave tehničke kulture važno je odabrati model kojim bi se implementiralo projektno učenje i nastava $u$ kurikulum. U tom smislu se model kontekstualnog učenja i razvoja učenika (slika 2) nameće kao optimalni teorijski okvir. koji se može koristiti kao podloga i okosnica kontekstualnog pristupa nastavi tehničke kulture.

\subsection{Primjena modela kontekstualnog učenja u nastavi tehničke kulture}

Spoznajni proces u nastavi tehničke kulture, koji se oslanja na kontekstualno učenje, odvija se kroz četiri etape (Purković i Kovačević, 2020):
1. Etapa uvida - uvid u tehničko tehnološku stvarnost i učenikovo vlastito shvaćanje;

2. Etapa pripremanja - prilagođavanje, osmišljavanje, planiranje i pripremanje za vlastito djelovanje;

3. Etapa realizacije - eksperimentiranje, isprobavanje, ispitivanje, izrada, sastavljanje;

4. Etapa valorizacije (evaluacije i refleksije) prezentacija, diskusija, refleksija, evaluacija.

Navedene etape predstavljaju ciklus refleksije kontekstualnog učenja i razvoja učenika. Ciklus je prikazan kao model (slika 2) iskustvenog učenja koji je ovdje adaptiran kako bi odgovarao specifičnostima nastave tehničke kulture (Purković, 2016; Purković i Kovačević, 2020). lako predstavlja proces učenja ovaj model se može primijeniti kao način organizacije učenja i poučavanja na makro razini (na razini kurikuluma) i mikro razini (na razini nastavne teme). Stoga primjena modela, odnosno, navedenih elemenata, može olakšati operativno planiranje i programiranje nastave tehničke kulture, odnosno, operacionalizaciju kurikuluma. Drugim riječima, model može poslužiti kao okvir za primjenu različitih strategija i pristupa učenju i poučavanju, pa tako i učenja temeljenog na projektima.

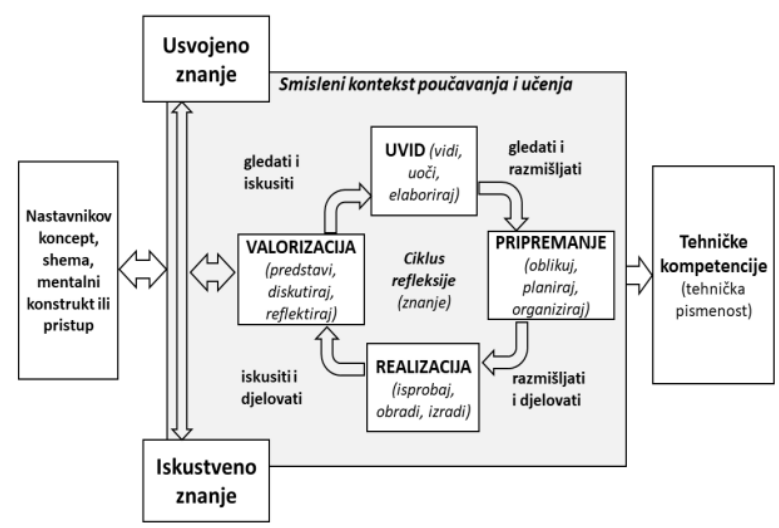

Slika 2. Model kontekstualnog učenja i razvoja učenika u tehničkoj kulturi

Spoznajni bi proces trebao započeti uvidom u neku vrstu tehnologije ili tehničko-tehnološku stvarnost gdje se pojavljuju i određeni problemski zadatci. Učenici moraju vidjeti i uočiti posebnosti onoga što promatraju. Uvid bi bio temelj za učenikovo vlastito tumačenje stvarnosti, a kontekstualizacija bi se očitovala u popratnim kontekstualnim materijalima. Učitelj bi vodio proces kognitivnim naukovanjem te bi tako pomogao i olakšao tumačenje i konstrukciju učeničkog znanja. Višestruko tumačenje učenicima pomaže u stjecanju kognitivne fleksibilnosti, što je važno za unapređenje njihovih spoznajnih procesa (Black i McClintock, 1995).

Poslije uvida slijedi etapa pripreme. U tehničkoj kulturi zahtijeva se složena priprema te je stoga 
prikazana kao zaseban dio ciklusa. Učenici će se pripremiti tako da suradnički osmisle, isplaniraju i organiziraju rad. Vrlo je važno dobro se pripremiti kako bi aktivnost dovela do željenih rezultata, a moguće su i neželjene posljedice. Poznata je stara izreka: „Priprema je pola posla“. Učenici će i u ovoj fazi koristiti dodatne kontekstualne materijale $s$ ciljem lakše pripreme i planiranja, a upute od strane učitelja bit će od krucijalne važnosti. Prema Purković i Bezjak (2015), spoznaja stečena tijekom prve dvije etape značajna je za usvajanje deklarativnih i konceptualnih znanja učenika. Na razini kurikuluma pripremanje uključuje i različite izolirane praktične aktivnosti (vježbe) kojima se učenik adaptira u radno okruženje te usvaja osnovna znanja i vještine koje će kasnije iskoristiti za realizaciju vlastitih zamisli. Postavlja se pitanje kako će onda učenici zapravo učiti? Učit će tako što će prolazeći kroz proces rješavanja različitih problema i rješavanje praktičnih zadataka prolaziti i kroz različite puteve i načine njihovog rješenja. Time će shvatiti kontekst i pozadinu onoga što rade.

Razmišljanjem i djelovanjem dolazi se do etape realizacije. Ovdje je važno da učenici isprobaju, prerade i izrade tehnički proizvod jer se kroz te akcije odvija proces učenja. Učenici uče situacijski, ali i nenamjerno, kao spontano djelovanje ili transakcija (Purković i Bezjak, 2015), što ujedno povećava vještine i znanja. Može se reći da se uči i na pogreškama. Važno je istaknuti kako je u kurikulumu ovo etapa u kojoj se realizira učenje temeljeno na projektima. Glavni preduvjeti za to su prihvaćanje takve strategije od strane učenika te razrada $i$ realizacija ideja koje su učenici sami inicirali. U suprotnom, odnosno, ako se ideja ili gotovi „projekt“ nametne učenicima, onda to više nije učenje temeljeno na projektima, već samo složena praktična aktivnost. Ipak, učitelj mora pripremiti i isplanirati projektnu nastavu. Kako onda postići da tema projekta bude učenička ideja, a da je učitelj unaprijed isplanira? Okviri koji su postavljeni kurikulumom već omeđuju i sadržaje koje učenik tijekom aktivnosti treba usvojiti, što već olakšava učitelju postupanje. Osim toga, učitelj je glavni moderator i facilitator (onaj koji olakšava aktivnosti učenicima). Stoga učitelj mora voditi mentalni proces razrade učeničke ideje, predlagati mogućnosti i dati određena ograničenja (okvire). Ova ograničenja ili okviri su usko povezani sa stvarnošću tehnologije i inženjerstva, a riječ je o zahtjevima partnera (kao obvezujućeg čimbenika projektne nastave) te ograničenja po pitanju resursa, materijala, opreme, ali i cijene krajnjeg proizvoda. Pri tom se učitelj ujedno treba postaviti sebi pitanje koje aktivnosti učenika će voditi do ostvarivanja ishoda učenja. Kad se uzme u obzir i to da učitelj najbolje poznaje svoje učenike, već će unaprijed moći pretpostaviti kakve teme projekta će zanimati učenike i moći će planirati nastavu. Osim toga, ako model (slika 2) promatramo sa stajališta primjene (implementacije) na cjelokupni kurikulum, tijekom etape uvida te etape pripreme učitelj će propitkivati želje, sklonosti i interese učenika te razgovarati $s$ njima o mogućnostima, potrebama i ograničenjima, a sve to s ciljem približavanja temama za predstojeći projekt. Tijekom ove dvije etape učitelj bi trebao imati dovoljno informacija na temelju kojih će moći predvidjeti, isplanirati i pripremiti učenje temeljeno na projektu.

Posljednju se etapu zaključuje s valorizacijom aktivnosti učenika. Vrlo je važno da na kraju projekta učenici provedu prezentaciju vlastitog rada, pri čemu treba inicirati njihovu diskusiju o vlastitom iskustvu. Učenici se reflektiraju na cjelokupnu aktivnost te ih se pri tome usmjerava na shvaćanje promjena koju je pojedina aktivnost izazvala na njima. lako se većina aktivnost izvodi timski, pa se sukladno tome provodi i refleksija, ne smiju izostati ni individualna objašnjenja i tumačenja. Pritom će učenici iznijeti svoje mišljenje i tumačenje vlastitim riječima te se podrazumijeva da će biti različitih mišljenja i ideja, što dalje potiče kognitivnu fleksibilnost učenika te razvoj samosvijesti o vlastitim interesima i sposobnostima. Proširuje se rječnik i spektar znanja učenika. Izražavanjem vlastitim riječima izražavaju se nove „postavke“ i informacije te učenici najbolje pamte ono što razumiju u vlastitom kontekstu. Ova etapa učitelju ujedno koristi kako bi mogao procijeniti u kojoj mjeri su ostvareni ishodi učenja, na temelju čega će ocijeniti postignuća učenika prema predviđenim elementima i kriterijima vrednovanja.

\subsubsection{Primjer implementacije projektne nastave u nastavi tehničke kulture}

Prethodno elaboriran teorijski model omogućuje implementaciju projektnog učenja i nastave $u$ kurikulum, što traži dodatna objašnjenja u kontekstu predmetnog kurikuluma tehničke kulture. Stoga je u nastavku iznesen primjer implementacije učenja temeljenog na projektima, odnosno, reducirani prikaz cjelokupnog ciklusa refleksije na razini kurikuluma za 8. razred osnovne škole (tablice 1 do 4). Za svaku etapu je naveden jedan ili više kontekstualnih pristupa nastavi (nastavni rad) te povezani ishodi učenja iz kurikuluma koji bi se trebali ostvariti na temelju takvih aktivnosti.

$U$ etapi uvida (tablica 1) učenicima se treba predočiti što neka tehnika i tehnologija znače za određeno društvo, zajednicu, pojedinca, ali i gospodarstvo. Ujedno se ovdje predstavljaju i odabrana zanimanja ljudi u određenom tehničkotehnološkom području. Uvid u tzv. makro-kontekst se najbolje postiže usidrenim učenjem, odnosno, prikazivanjem dobro osmišljenih filmova izvorne 
stvarnosti, a ponekad i stručnim ekskurzijama. Prikazivanje je popraćeno analizom i sistematizacijom sadržaja kroz razgovor s učenicima. U 8. razredu učenicima treba dati uvid u sustav proizvodnje i prijenosa električne energije, električnih instalacija $u$ stambenom objektu te u važnost i značaj električnih, elektroničkih, automatiziranih i robotiziranih naprava i uređaja u suvremenoj proizvodnji i svakodnevnom životu. Cilj ove etape je učenicima dati smisao i značenje sadržaja koji će se kasnije obrađivati, a trajanje aktivnosti može biti od 4 do 6 sati nastave. Tijekom ove etape se ujedno ispituju sklonosti i interesi učenika koje treba uskladiti s aktivnostima koje slijede u nastavi.

\begin{tabular}{|c|c|}
\hline Nastavni rad & Ishodi učenja \\
\hline $\begin{array}{l}\text { Usidreno učenje: } \\
\text { prikazivanje i analiza } \\
\text { filmskih materijala: } \\
\text { proizvodnja i prijenos } \\
\text { električne energije; } \\
\text { električne instalacije } \\
\text { u stambenom } \\
\text { objektu; proizvodnja i } \\
\text { primjena električnih, } \\
\text { automatiziranih i } \\
\text { robotiziranih naprava } \\
\text { u suvremenoj } \\
\text { proizvodnji i } \\
\text { svakodnevnom } \\
\text { životu; zanimanja u } \\
\text { području } \\
\text { elektrotehnike, } \\
\text { automatike, robotike. }\end{array}$ & $\begin{array}{l}\text { Opisuje sustav jednostavne } \\
\text { električne instalacije; } \\
\text { Objašnjava način proizvodnje i } \\
\text { prijenosa električne energije; } \\
\text { - Objašnjava utjecaj elektrana na } \\
\text { okoliš; } \\
\text { Objašnjava ulogu električnih } \\
\text { trošila u kućanstvu; } \\
\text { - Navodi i objašnjava primjenu } \\
\text { elektroničkih sklopova i uređaja } \\
\text { u svakodnevnom životu i } \\
\text { različitim djelatnostima; } \\
\text { Opisuje tehničke značajke, } \\
\text { primjenu i vrste robota u } \\
\text { području automatizacije; } \\
\text { - Objašnjava dobrobiti primjene } \\
\text { električnih tvorevina; } \\
\text { Opisuje moguće štetne učinke } \\
\text { na prirodni okoliš i mjere } \\
\text { zaštite; } \\
\text { Razmatra postupke } \\
\text { zbrinjavanja (otpada i sl.); } \\
\text { - Razmatra utjecaj proizvodnje } \\
\text { električnih tvorevina na okoliš; } \\
\text { Obrazlaže važnost energetske } \\
\text { učinkovitosti. }\end{array}$ \\
\hline
\end{tabular}

Tablica 1. Nastavne aktivnosti i ishodi učenja u etapi uvida

U etapi pripremanja (tablica 2) glavni cilj je učenike osposobiti za uspješno korištenje tehničkih sredstava, odgovarajuće dokumentacije, kao i za realizaciju praktičnih aktivnosti na siguran način. Najbolja priprema za to je provedba jednostavnih vježbi, odnosno izoliranih praktičnih aktivnosti, kojima će se učenici upoznati sa shemama, elementima, strujnim krugovima, simbolima, te sredstvima i tehnologijom izrade i sastavljanja jednostavnih električnih instalacija, elektroničkih sklopova i automatiziranih ili robotiziranih naprava. Procjena postignuća učenika se u ovoj etapi provodi isključivo formativno, odnosno, usmjerena je daljnjem razvoju i učenju. Ovakve aktivnosti bi trebale trajati između 10 do 12 sati nastave, što znači da bi se prema sadašnjoj satnici i uobičajenoj praksi nastave tehničke kulture odvijale do kraja polugodišta.

\begin{tabular}{|l|l|}
\hline \multicolumn{1}{|c|}{ Nastavni rad } & \multicolumn{1}{|c|}{ Ishodi učenja } \\
\hline Izolirane praktične & Razlikuje vrste shema; \\
aktivnosti: & Razlikuje simbole elemenata u \\
jednostavne vježbe & elektrotehnici i elektronici; \\
crtanja i analize & Crta sheme u elektrotehnici i \\
električnih i & elektronici; \\
elektroničkih shema; & - Razlikuje materijale prema \\
sastavljanje strujnih & električnoj vodljivosti i drugim \\
krugova; izrada i/ili & svojstvima; \\
sastavljanje električne & Opisuje sustav jednostavne \\
instalacije; izrada & električne instalacije; \\
elektroničkog sklopa; & Objašnjava svojstva pojedinih \\
Sastavljanje & elemenata kućne električne \\
automatiziranog ili & instalacije; \\
robotiziranog sklopa. & Sastavlja model strujnoga kruga \\
& iz kućne električne instalacije; \\
& Sastavlja elektronički sklop; \\
& Navodi osnovne električne \\
& veličine i mjerne jedinice; \\
& Opisuje svojstva elektroničkih \\
& elemenata; \\
& Mjeri električne veličine; \\
& sastavlja elektronički sklop. \\
\hline
\end{tabular}

Tablica 2. Nastavne aktivnosti i ishodi učenja u etapi pripremanja

$U$ etapi realizacije (tablica 3 ) glavnu aktivnost čini projektno učenje i nastava koja bi se trebala odvijati u malim skupinama učenika i biti usklađena $s$ njihovim interesima. lako je rad svih učenika usmjeren istom cilju učitelj treba voditi računa da učenik u skupini obavlja one poslove i zadaće kojima je najviše sklon. U 8. razredu učenici mogu raditi na složenijem projektu automatizacije ili upravljanja određenim uređajima ili procesima u kućanstvu, školi ili drugom, njima poznatom okruženju. Projekt kreće razradom ideje - osmišljavanjem, dizajniranjem i konstruiranjem proizvoda, crtanjem različitih shema, nastavlja se planiranjem sredstava, tehnologije i raspodjelom poslova i zaduženja te kulminira izradom proizvoda. Pritom se integriraju spoznaje iz elektrotehnike, elektronike, automatike ili robotike, što čini jezgru tehničkih sadržaja u 8. razredu. Primjerice, u 8. razredu tijekom projekta učenici mogu najprije izraditi dio električne instalacije na koju će spojiti vlastiti ispravljački sklop koji će se potom koristiti za pogon složenijeg vlastitog proizvoda za automatsku regulaciju procesa ili posla. Osnovu potonjeg sklopa može činiti neka mikroupravljačka platforma (Arduino, Micro:bit i sl.) na koju se ciljano priključuju određeni senzori, aktuatori ili komunikacijska sučelja u skladu $s$ funkcijom proizvoda. Proizvod se ujedno stavlja u funkciju uporabom računala i IKT-a. Projektne 
aktivnosti trebaju uključivati i ispitivanje funkcionalnosti, doradu i eventualno usavršavanje $i$ inoviranje proizvoda. lako učitelj ne nameće temu, vještim zahtjevima partnera i/ili inženjerskim ograničenjima po pitanju materijalnih resursa, može usmjeriti tijek razrade ideje i realizacije projekta. Tijekom projektnih aktivnosti se s učenicima može provesti i stručna ekskurzija koja, ovisno o projektu, može imati za cilj upoznavanje tehničko-tehnološke, radno-socijalne ili proizvodno-ekonomske stvarnosti. Ovakav projektni rad učenika treba trajati najmanje 10 sati i nipošto ne završava stavljanjem u funkciju sklopovlja ili proizvoda.

\begin{tabular}{|c|c|}
\hline Nastavni rad & Ishodi učenja \\
\hline $\begin{array}{l}\text { Projektno učenje i } \\
\text { nastava: složenija } \\
\text { projektna aktivnost u } \\
\text { malim skupinama, } \\
\text { usklađena s } \\
\text { interesima i } \\
\text { sklonostima učenika } \\
\text { (npr.: Model kuće sa } \\
\text { solarnom rasvjetom, } \\
\text { Automatizacija } \\
\text { zalijevanja vrta, } \\
\text { Upravljanje } \\
\text { električnim trošilima u } \\
\text { kućanstvu i sl.). } \\
\text { Stručna ekskurzija: } \\
\text { organizirani posjet } \\
\text { tvrtki ili organizaciji } \\
\text { koja se bavi } \\
\text { automatizacijom, } \\
\text { proizvodnjom } \\
\text { električnih uređaja, } \\
\text { projektiranjem ili } \\
\text { održavanjem u } \\
\text { području } \\
\text { elektrotehnike, } \\
\text { automatike ili } \\
\text { robotike (ovisno o } \\
\text { posebnostima } \\
\text { projekta). }\end{array}$ & $\begin{array}{l}\text { - Razlikuje vrste shema; } \\
\text { - Razlikuje simbole elemenata u } \\
\text { elektrotehnici i elektronici; } \\
\text { - Crta sheme u elektrotehnici i } \\
\text { elektronici; } \\
\text { - Objašnjava značenje i namjenu } \\
\text { strujnih krugova prikazanih } \\
\text { shemama; } \\
\text { - Opisuje sustav jednostavne } \\
\text { električne instalacije; } \\
\text { - Objašnjava svojstva pojedinih } \\
\text { elemenata kućne električne } \\
\text { instalacije; } \\
\text { - Sastavlja model strujnoga kruga } \\
\text { iz kućne električne instalacije; } \\
\text { - Sastavlja elektronički sklop; } \\
\text { - Navodi osnovne električne } \\
\text { veličine i mjerne jedinice; } \\
\text { - Opisuje svojstva elektroničkih } \\
\text { elemenata; } \\
\text { - Mjeri električne veličine; } \\
\text { - Opisuje razliku upravljanja } \\
\text { sustavom s povratnom vezom i } \\
\text { bez povratne veze; } \\
\text { - Opisuje tehničke značajke, } \\
\text { primjenu i vrste robota u } \\
\text { području automatizacije; } \\
\text { - Opisuje ulogu računala u } \\
\text { automatskom sustavu; } \\
\text { - Izrađuje model automatizirane } \\
\text { tvorevine s povratnom vezom; } \\
\text { - Navodi i objašnjava primjenu } \\
\text { elektroničkih sklopova i uređaja } \\
\text { u svakodnevnome životu i } \\
\text { različitim djelatnostima; } \\
\text { - Objašnjava dobrobiti primjene } \\
\text { električnih tvorevina; } \\
\text { - Objašnjava postupke pravilne } \\
\text { uporabe i potrebu održavanja; } \\
\text { - Razmatra onke } \\
\text { zbrinjavanja; } \\
\text { - Razmatra utjecaj proizvodnje } \\
\text { električne tvorevine na okoliš. }\end{array}$ \\
\hline
\end{tabular}

Tablica 3. Nastavne aktivnosti i ishodi učenja u etapi realizacije
$U$ etapi valorizacije (tablica 4) učenici svoju dokumentaciju trebaju srediti i pripremiti predstavljanje vlastitog projekta i iskustava. Svaka skupina i pojedini članovi trebaju predstaviti vlastiti proizvod, dokumentaciju i aktivnosti koje su izvodili tijekom projekta. Tijekom ovog vremena provodi se razgovor (refleksija) o iskustvima, diskusija o stečenim spoznajama i učenička samoevaluacija. U konačnici, učitelj provodi evaluaciju proizvoda, dokumentacije, prezentacijskih vještina i pokazanog znanja učenika. Ovaj dio nastave ustvari predstavlja završni dio projektnog učenja kojem bi učitelj trebao posvetiti od 4 do 6 sati nastave.

\begin{tabular}{|c|c|}
\hline Nastavni rad & Ishodi učenja \\
\hline $\begin{array}{l}\text { Predstavljanje, } \\
\text { refleksija evaluacija: } \\
\text { učeničko } \\
\text { predstavljanje } \\
\text { vlastitih uradaka i } \\
\text { aktivnosti; razgovor } \\
\text { (refleksija) o } \\
\text { iskustvima učenika; } \\
\text { predstavljanje } \\
\text { istraženih zanimanja; } \\
\text { diskusija o stečenim } \\
\text { spoznajama; } \\
\text { modeliranje i } \\
\text { sistematizacija } \\
\text { spoznaja; } \\
\text { vrednovanje } \\
\text { postignuća učenika. }\end{array}$ & 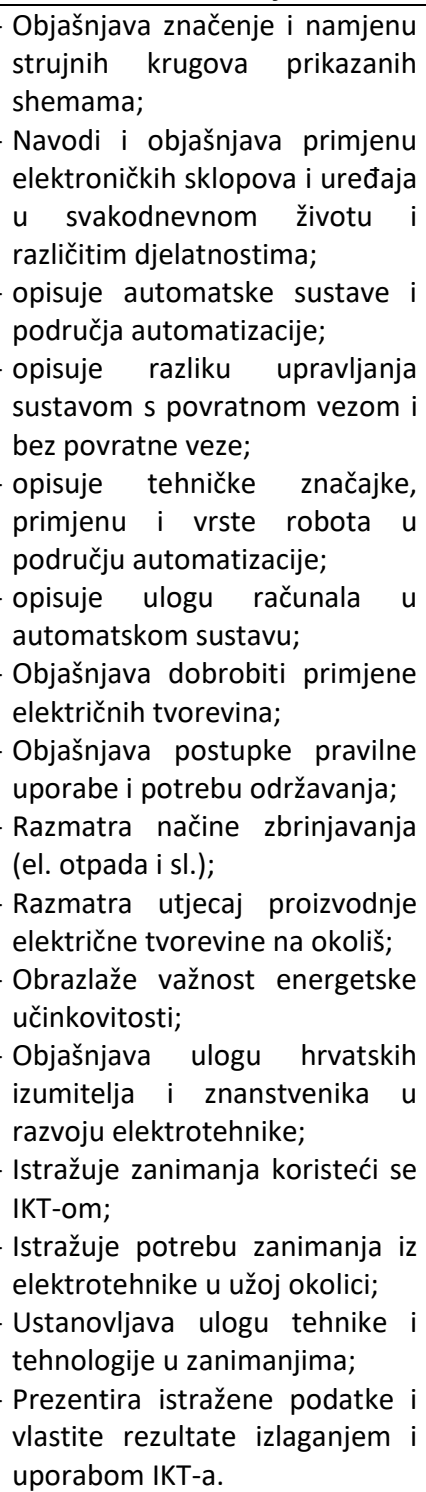 \\
\hline
\end{tabular}

Tablica 4. Nastavne aktivnosti i ishodi učenja u etapi valorizacije

Uz navedene aktivnosti, tijekom ovog procesa učitelj treba prirediti brojna i dobro osmišljena (neizravna) pitanja kojima će provoditi razgovor s učenicima, 
procijeniti razinu ostvarenosti ishoda učenja, ali ih i voditi kao ostvarivanju tih ishoda. Dakle, ovakvim pitanjima se utvrđuje ostvarenost ishoda učenja, ali ne samo zbog ocjenjivanja, već i zbog upotpunjavanja stečenih spoznaja, postavljanja učenikovih spoznaja u određeni sustav te zbog završnog modeliranja i usmjeravanja učenikovih stavova i vrijednosti.

Predočeni primjer implementacije projektnog učenja i nastave trebao bi učiteljima-praktičarima poslužiti kao model i poticaj za operacionalizaciju kurikuluma vlastite nastave.

\section{Zaključak}

Tehnički odgoj i obrazovanje je neizostavna komponenta općeg obrazovanja koja je iznimno važna za razvoj učenika, ali i za razvoj gospodarstva zemlje. Kako se u svijetu konstantno događaju promjene, sukladno tome potrebne su i promjene tradicionalnog načina poučavanja učenika. $U$ tom smislu učenici trebaju aktivno sudjelovati u nastavi kako bi razvili vještine i kompetencije koje odgovaraju zahtjevima modernog doba. Kako bi se ovi zahtjevi ispunili, u nastavu se uvode kontekstualni pristupi učenju i poučavanju među kojima učenje temeljeno na projektima postaje ključno za razvoj tehničkih, ali i društvenih kompetencija učenika.

$S$ obzirom da projektno učenje nije jednostavno integrirati u postojeća vremensko-organizacijska ograničenja obrazovnog sustava važno je odabrati optimalni pristup ili model za takvu integraciju. Primjenom modela kontekstualnog učenja i razvoja učenika na razini kurikuluma dobiva se optimalni način za integraciju projektne nastave u kurikulum tehničke kulture. Pri tom se $u$ etapi uvida dominantno koristi usidreno učenje, a u etapi pripremanja izolirane praktične aktivnosti učenika. Učenje temeljeno na projektima se integrira u etapi realizacije te tako zauzima središnje mjesto $u$ kurikulumu, tijekom kojega se realizira većina predviđenih ishoda učenja. Završnu etapu valorizacije čini učeničko predstavljanje vlastitih rezultata, tijekom kojega se provodi diskusija, refleksija i vrednovanje postignuća učenika.

Unatoč jasnim smjernicama i razradi predloženog modela projektna nastava nije nimalo lagan zadatak za učitelja te može biti izazovna i iskusnim učiteljima. Pri tom problemi mogu biti povezani s pokretanjem projekta, razradom ideja, vođenjem projektnog učenja, ali znanjem o načinima pripremanja ovakve nastave. Zbog toga je nužna temeljita priprema nastavnika, ali i učenika, čemu može doprinijeti primjer koji je elaboriran $u$ ovom radu. Pri tom se učenika treba stalno motivirati za aktivno sudjelovanje, jer je upravo motivacija ključ uspjeha pri izradi složenog projekta. Unatoč tome, glavni problem s kojim se susreće nastava tehničke kulture i nadalje je nedostatak vremena za realizaciju složenijih projektnih aktivnosti, što ukazuje na nerazumijevanje značaja ove nastave za razvoj kompetencija u tzv. STEM području. Stoga će se tek revalorizacijom vrijednosti tehničke kulture od strane obrazovnih vlasti moći unaprijediti kvaliteta nastave i nastavnika tehničke kulture i steći primjereni uvjeti za implementaciju projektnog učenja. Na taj način će se potaknuti toliko željena inovativnost i kreativnost učenika te će se steći uvjeti za empirijsku valorizaciju predloženog modela učenja i razvoja učenika.

\section{Literatura}

Berns, R. G., Erickson, P. M. (2001). Contextual Teaching and Learning: Preparing Students for the New Economy. The Highlight Zone: Research (C) Work No. 5. https://files.eric.ed.gov/fulltext/ ED452376.pdf

Bezjak, J. (2009). Contemporary forms of pedagogic $P U B-B J$. Klagenfurt: LVM.

Black, J., B., McClintock, R., O. (1995). An Interpretation Construction Approach to Constructivist Design. U: B. Wilson (ur.), Constructivist learning environments. Englewood Clifs, NJ: Education Technology Publications.

Bratko, D. Ljubin, T., Matijević, M. (2000) Učenička evaluacija kurikuluma "Aktivna/efikasna škola" // Napredak, 141 (2000), 2; 156-169.

CORD (1999). Teaching Science Contextually: The Cornerstone of Tech Prep. USA, Waco: CORD Communications, Inc.

Crawford, M., L. (2001). Teaching Contextually: Research, Rationale, and Techniques for Improving Student Motivation and Achievement in Mathematics and Science. Waco: CORD.

Frost, A., A. (2014). Synthesis of Knowledge Management Failure Factors, http://www.knowledge-managementtools.net/failure.html (14.12.2016.)

Jukić, T. (2010). Odnos kurikuluma i nastavnog plana i programa. Pedagogijska istraživanja, Vol. 7 (1), 55-64.

Kokotsaki, D., Menzies, V., Wiggins, A. (2016). Project-based learning: a review of the literature. Improving schools, 19 (3). 267-277.

Kolb, D. A. (1984). Experiential learning: experience as the source of learning and development. Englewood Cliffs, NJ: Prentice Hall. 
Lipika, G., Pooja A., Rajnish, S., Madhu C., (2014). Project based Learning - an Enhanced Approach for Learning in Engineering, Proceedings of the International Conference on Transformations in Engineering Education ICTIEE 2014, Natarajan, R. (Ed.), Springer, 2015 (ISBN 978-81-322-1931-6).

Milat, J. (1996). Tehnička kultura bitna je odrednica sustava obrazovanja. Društvena istraživanja, 1(21), 109-128.

Milat, J. (2005) Pedagoške paradigme izrade kurikuluma. Pedagogijska istraživanja, 2(2), 199208.

MZOŠ (2006). Nastavni plan i program za osnovnu školu. 304-309, https://www.azoo.hr/(20.7.2020.)

NN 7/2019. Odluka o donošenju kurikuluma za nastavni predmet Tehničkekulture za osnovne škole u Republici Hrvatskoj (22.1.2019.)

Prince, M. J., Felder, R. M., (2006). Inductive Teaching and Learning Methods, Definitions and Research Bases, Journal of Engineering Education, 95(2), 123-138.

Purković, D. (2016) Elementi kontekstualnog pristupa učenju i poučavanju kao čimbenici uspješnosti nastave Tehničke kulture. Doktorski rad. Split: Sveučilište u Splitu, Prirodoslovno-matematički fakultet.

Purković, D., Bezjak, J., (2015). Kontekstualni pristup učenju i poučavanju u nastavi temeljnog tehničkog odgoja i obrazovanja, Školski vjesnik, 64(2015),1, 131-152.

Purković, D. (2015). Realiteti tehničke kulture. Rijeka, Filozofski fakultet Sveučilišta u Rijeci.

Purković, D. (2018). Conceptualization of technology as a curriculum framework of technology education. In I. Milicevic (Ed.), Proceedings TIE 2018 (pp. 3-11). Čačak: University of Kragujevac, Faculty of Technical Sciences.

Purković, D., Kovačević S. (2020). Hierarchical structure of the importance of teaching context in general technology education. Knowledge International Journal, 40 (2020), 2, 317-325.

Thomas, J. W. (2000). A review of research on project-based learning. San Rafael, CA: Autodesk Foundation.

Visković, I. (2016). Projektna nastava kao područje unaprijeđenja kvalitete škole. Školski vjesnik: časopis za pedagogijsku teoriju i praksu, Vol. 65, Tematski broj, 381-391.

Verbitsky, A., A., Kalashnikov, V., G. (2012). Category of "Context" and Contextual Approach in
Psychology. Psychology in Russia, State of the Art, 5, 117-130.

\section{Application of project-based learning in the teaching of Technical Culture}

\section{Abstract}

The development of each country's economy is closely linked to the development of technology and technical education. Technological and engineering knowledge is characterized by diversity and highly unpredictable development dynamics. Therefore, this area of learning and teaching is subject to change and harmonization with the dynamics of technology development and the problems of successfully achieving the goals of teaching. In order to neutralize these problems, contextual approaches to learning and teaching, such as project-based learning, need to be implemented in modern teaching. This paper elaborates on such implementation within the curriculum of the subject Technical Culture. A model of contextual learning and student development was used as a template for implementation. In this sense, project teaching and learning occupy a central place in the curriculum, during which most learning outcomes are achieved. The paper also provides an example of implementation for 8th grade, which can make it easier for teachers and practitioners to operationalize their own curriculum. At the same time, the teacher remains the main creator and moderator of teaching, where it is important to set certain restrictions for students anticipate suggestions for solving problems, and guide students to the successful completion of activities. Nevertheless, the real effect of applying this approach on student achievement will be possible to evaluate only if it comes to life in real teaching practice, which is expected in the near future.

Keywords: contextual approaches, curriculum, project-based learning, technical culture, technology education. 